\title{
China as a Global Destination for International Students
}

\author{
Gao Wei ${ }^{1,2}$, Wang Lin $^{3}$, Yan Jingdong ${ }^{1} \&$ Wu Yanxiong ${ }^{4}$ \\ ${ }^{1}$ School of Management, Wuhan University of Technology, Wuhan, China \\ ${ }^{2}$ Internataional Exchange College, Hankou University, Wuhan, China \\ ${ }^{3}$ Admission Unit, Hankou University, Wuhan, China \\ ${ }^{4}$ Jiyang College of Zhejiang A\&F University, Zhuji, China \\ Correspondence: Yan Jingdong, School of Management, Wuhan University of Technology, Wuhan 430000, \\ Hubei, China. E-mail: yjdong02@163.com; Wu Yanxiong, Jiyang College of Zhejiang A\&F University, Zhuji \\ 311800, Zhejiang, China. E-mail: 13601213097@163.com
}

Received: December 31, 2019

Accepted: February 7, 2020

Online Published: February 29, 2020

doi:10.5539/jpl.v13n1p135

URL: https://doi.org/10.5539/jpl.v13n1p135

\begin{abstract}
This qualitative study aimed to explore the reasons why China has become a global destination for international students. Recently, the enrollment of International Students has increased at Chinese Universities. The study aims to understand why such International Students from Bangladesh, India, and Pakistan choose to study in China for tertiary education rather than studying in any US or European Universities. To conclude the study, a mixed-method research methodology was used by using focus group discussions and descriptive statistics from two different surveys. The research establishes that the maximum of the international students have chosen China as their study destination is because of safety and security at the campus, proximity with their homeland, low cost of education and accommodation, and a strong perception of prospective job opportunities upon completion of their degrees. The study suggested that Chinese Universities can initiate different plans/ schemes in attracting international students from different countries of the world.
\end{abstract}

Keywords: global education, higher education, international students, Chinese universities

\section{Introduction}

Tertiary educations have developed more globalized and has observed an extraordinary growth in the number of international students globally, while the majority of them belong to China. The Institute of International Education (IIE) released a report in 2015 on Open Door Reports on International Educational Exchange, which revealed a tremendous increase regarding Chinese students studying in American universities and colleges, contributing $31 \%$. Similarly, apart from the USA, China is providing a huge quantity of students to the UK, Australia, Canada, Japan, and New Zealand by 2014 (Jiani, M. A. 2017). China has been known as a major "sending" country, in terms of mobility, indicating the loss of its talent and brain drain to developed countries. Nevertheless, the Chinese role as a "receiving" country has been ignored, especially in terms of foreign students from different countries of the world.

Though China has huge numbers of students in terms of "sending" nation, it has now rapidly revolutionized itself into one of the biggest "receiving" countries (Wei 2013). An IIE's report, 2015 on Open Doors revealed that Mainland China is a home for $8 \%$ intentional students, passing Germany $7 \%$ and France $7 \%$, and stand at the third-ranked country for mainly international college students, following the USA (22\%) and the United Kingdom (UK) about 11\%. The Ministry of Education in China shared statistics in 2018 concerning the international students studying in Mainland China from 196 countries are a total 492,185 presenting a remarkable increase of 3,013 students $(0.62 \%)$ as compared to the previous year 2017 (MOE 2018). The Government of China has issued a Plan for Study in China, proposes that the international students studying in Mainland China in elementary, secondary, and higher education will reach 500,000 by 2020 (China 2012).

\subsection{Historical Background of Higher Education for International Students}

China has started accepting international students before more than 1400 years, during the Sui Dynasty (581-618 $\mathrm{AD})$. The education in China, particularly for international students, has undergone numerous phases of development since the inception of the People's Republic of China (PRC) in 1949 (Li 2000). The foundation of 
higher education for international students has laid down during the first stage of development, which lasts for a decade and a half under PRC (1950-1965). A huge number of international students flocked to China as an exchange student during the country has closed relations with the Soviet Union and other socialist countries from Eastern Europe (Jiani, M. A. 2017). The Bandung Conference in 1954 concluded with the extension of Chinese policy regarding the acceptance of students from underdeveloped countries from Asia, Africa, and Latin America to fulfill its promise and offer international assistance. However, such a policy could not attract many international students because of the low level of higher education.

The second stage of educational development has considered an impediment and retrieval for the international students in China, which lasted for 12 years (1966-1977). The Cultural Revolution of 1966 had extremely affected the improvement of higher education institutions of China, particularly the higher education institution, were affected the most. Consequently, international student exchange programmes remained suspended for seven years (1966-1972) (Waldrop, N. 2016). After the Cultural Revolution in the 1970s, the country re-established its diplomatic relationship with 124 countries around the globe, intending to resume the development and relationship to attract to recommence the education of international students.

However, preliminary progress towards the development of education for international students in China has witnessed during 1978-1989. In 1978, the country initiated reforms and introduced new policies to develop higher education, particularly education for international students. In the wake of policy reforms that open gates for international students to study on self-finance basis in China, two following documents had approved by the State Council, (i) Regulations on Work-Related to International Students (Revised Version) 1979, and (ii) Charge Students for Self-paying International Students, 1979 (Chen, K. 2016).

The inclusion of both administrative and incentive mechanisms for the educational development in China is considered from1990 to 1998; it can be called as the fourth stage of development of education for international students in China. The Ministry of Education, Government of China, took a landmark initiative by establishing China Scholarship Council in 1996 to organize, manage, and finance to Chinese students who intend to study abroad and international students from different countries who intend to study in China. This period is believed to be a period of the rapid development of education for international students in China (Ibid: 51).

The following evidence shows the rapid development of education, particularly for international students who started in the twenty-first century. Firstly, it has been observed a significant increase in the number of international degree students studying in China. In 2018, 492,185 students from 196 different countries around the globe pursued their studies in 1004 Chinese higher education institutions in 31 provinces/ autonomous regions/ provincial-level municipalities, showing an increase of 3,013 students or $0.62 \%$ compared to 2017 (Ministry of Education, China; 2019). Secondly, a huge number of higher education institutions initiated the acceptance of international students. A remarkable increase has shown in the number of such institutions, which were only 23 in 1970, while in 2018, 1004, higher education institutions were accepting international students to study in China (Ibid). Thirdly, a significant increase in the number of students from different countries with diversified backgrounds is noticed. The statistics of the top ten international students studying in China from different countries are from South Korea, Thailand, Pakistan, India, United States, Russia, Indonesia, Laos, Japan, and Kazakhstan (Ibid). Fourth, the numbers of scholarships by the Chinese Government Scholarship as well as a two-pronged agreement by the government with several foreign countries, have been amplified for the foreign students. Furthermore, apart from the scholarship provided by the Chinese government, several scholarships under Confucius Institutions, Provincial Governments, and municipal administrations, universities offering higher education, foreign governments, and business concerns are being offered.

Similarly, China openly welcomed international students to be hired in Chinese higher education institutions. President Xi Jinping instructed during his address on the occasion of National Work Conference on Studying Abroad in 2014 that the mobility of students for both going abroad and coming to China should for international education and exchange programme be facilitated (Ministry of Foreign Affairs PRC, 2014). Consequently, the State Council initiated an Overall Plan for Coordinating and Advancing the Construction of First-Class Universities and First-Class Discipline on $5^{\text {th }}$ November 2015, which necessitates the universities and different disciplines to work closely to be able to acknowledge as among the world's top universities by 2020 .

The plan aims to strengthen Chinese universities by the middle of the twenty-first century and disciplines qualitatively and quantitatively to compete with the global front-runner universities. Furthermore, the Overall Plan states that a strong focus on creating an enabling environment for teaching and research which will obliviously attract highly qualified international students. Moreover, the plan stressed the international competitiveness of Chinese higher education that necessarily depicts China as a country that has a strong focus 
on higher education and, most importantly, emphasizes "internationalization...as one of the important ways to build China's world-class research universities" (Huang 2015). A representative of the Confucian Model, Mainland China is fully empowered that can effectively enhance and form the structures, funding, and, most importantly, the Chinese government is determined in increasing investment to be recognized as one of the world-class universities (Maringson 2011).

\section{The Globalization of Tertiary Education}

The globalization of tertiary education and increased growth in the enrollment of foreign students in different universities around the globe has been observed (Shuhong et al., 2018). According to OECD (2019), more than 5 million students are enrolled in several institutions outside of their homeland till 2018, while more than half of these students have come from Asia. The choice of destination of mostly students was English speaking countries and Western-European countries (Maringe, F., \& Foskett, N. (Eds.) (2012). The study further explains that the majority of the international students choose to study in the US, which is around $17 \%$ of the total world international student population.

Furthermore, the study indicates that around 1,078,882 international students were enrolled in the US during the academic years 2016-2017, which shows an increase of 3.4\% percent as compared to the previous year (IIE, 2017). Having 50\% of the total international students in the United Kingdom, Australia, Germany, and France, followed by the US. Although, it is noteworthy, that the above stated five countries have considered as the top destination for international students for time, however, during the past decade some Western Countries have observed decline while China, Korea, Singapore, and Malaysia have seen a predominant role in the enrollment of international students (Jon et al., 2014). The direction of the flow of international students has moved from "east to west and south to north" to "east to east" (Ferencz, I. 2015). In another way, students from Asian countries have started selecting abroad in other Asian Countries, contrary to Western and European Countries (UNESCO, 2018).

Several factors result in the choice of an international study to study to any overseas country. One of the important factors which help to comprehend the migration of international students hs considered to be the resources. A theory of "push-pull" model has introduced to explain this phenomenon of trend that suggests to students to "pushed" out of their countries due to scare educational resources and are "pulled" out of their homeland to any foreign country to admission in the better educational resources and institutions (Ahmad, A. B., \& Shah, M. 2018). Apart from the assumptions of the "push-pull" model, a study explained this occurrence in which he compared international students in studying in China, Hong Kong, and Macau. The study revealed many important factors had a great significance on the choice of the study, such as "quality, facilities and resources, curriculum, international mobility following graduation, and access to scholarships" (Li and Bray 2007). Similarly, another study explained in its research that international students from different private university in China establish that most international students around the globe are concerned with educational quality such as uniqueness in the curriculum, inexpensive living cost, and other aspects related to visa process and fee, safety and geographical location of the university (Jon, J. et al. 2014). Another study concluded that three main features which attract international student to study in China, covering the cost, quality, and culture (Liu, Y., Kamnuansilpa, P., \& Hirofumi, A. (2018).

\section{Research Methodology}

A qualitative study conducted by (Ying L. et al., 2018) on a constructive research paradigm to comprehend the reasons why China is the destination for international students for higher education. To be able to complete this study, two surveys and a focus group interview have used. Wells, Hirshberg, Lipton, and Oakes contended the importance of constructivist research paradigm which is supplemented by "tentative, inductive, and interpretive form of data collection and analysis" (2000, p. 123).

Ten students from different nationalities and disciplines from the China University of Geoscience, Wuhan, China were selected to participate in the focus group interview. There were three female students, and seven were male students; their students had enrolled in a bachelor's degree programme, and seven are enrolled in a master's degree programme. The interviewers were asked the question, "Why did you choose to study at the Chinese University" to complete this research. So, no "priori categories" restricted their creativeness on this particular topic. The length of the focus group interview was extended to 40 minutes, and the same was documented and analyzed with the help of the Research Assistant later on. The recorded notes returned to the researchers and later on the same has given to the participants for authentication of such transcripts. The collected notes were analyzed on the subject matter of question and categories assembled from the discourses illustrated by the participants. 
The results of the FGD are supported in establishing two different surveys, one, the international students enrolled and studying in Chinese Universities, and second the Educational Agents from Bangladesh, India, and Pakistan. Such Educational Agents recruit students to study tertiary/higher education and training institutions outside of China and are responsible for providing significant information about the possible destination in terms of the foreign country and educational institutions for potential students. The first survey was conducted to observe the prospects and profiles of such international students studying in China. The second survey was conducted to observe the prospects and profiles of Educational Agents from Bangladesh, India, and Pakistan, and primarily to validate the impact of such Educational Agents on the International Students while choosing their progressive destination for study abroad. The survey was conducted online by using "SurveyMonkey" to every fifth international student listed as studying at Chinese universities and to 15 Educational Agents working in Bangladesh, India, and Pakistan.

This systematic selection process was intended to reproduce the number of international students studying in Chinese universities. The survey was based on the open-ended and closed-ended questions. Furthermore, descriptive statistical analysis was used to calculate the closed-ended questions dedicated to classifying themes and categories construed from the thesis drawn by the participants. The response by the 250 students was received during the four months, accounted for a 40 percent response rate. The next section of the paper signifies the findings of the study conducted by using two different approaches, such as surveys and focus group interviews.

\section{Discussion and Analysis}

\subsection{Focus Group Discussion on International Education}

The discourse analysis was used to analyzed and understand why international students opt to study at Chinese Universities during the focus group interview/discussion. The discourse analysis illustrates the ways of thinking of any societies based on cultures, which defines the limitations, particularly in languages and social practices (Knowles, J. G.; Cole, A. L. (2008). There is a variety of competition and conflicting discourses impacted by the vast society within the international tertiary education. The focus group analysis discovered that international students have brought up a variety of discourses that are available on media and the internet, containing the discourse of international exposure, safety/ racism, availability of jobs, financial hubs of emerging enterprises, and study cost. All the discourse will be discussed in turn.

\subsection{International Exposure}

The OECD (2019) discusses that since education, civilizations, and economics are becoming more globalized, students consider international exposure during their studies as competitiveness in the job market. A recent study by LIU Ying, Peerasit KAMNUANSILPA, Ando HIROFUMI (2018) supports that discourses of international/global experience to international students studying in China will assure that these students will gain "international exposure and (a) global outlook" (p.114). Four out of ten students were asked a question why they chose to study outside of their home country, and their interview revealed the following discourses:

"To get more of global exposure" (Focus Group Discussion, $3^{\text {rd }}$, November 2019)

"Probably to get more international exposure" (Focus Group Discussion, $3^{\text {rd }}$, November 2019)

"Get to more exposure" (Focus Group Discussion, $3^{\text {rd }}$, November 2019)

"The added advantage was the exposure, which we are getting" ((Focus Group Discussion, $2^{\text {nd }}$, September 2019).

All ten students were selected from the school of management sciences and business administration for the focus group discussion; therefore, it can be said that studying business in China may have broadened their business understanding as well as future prospects for their job and career. Similarly, OECD (2019) also contends that it may be one of the reasons that international students selected China for travel and higher education.

\subsection{Safety of the Students/ Bigotry}

Robyn and Abhishek (2011) discuss that a safe environment is considered to be the prime concern for international students while choosing the destination for higher education. Some of the students from the focus group discussion also pointed out this discourse as a piece of important advice given by media (Wen, W., Hu, D., Hao, J. 2018). The students also stated that their governments issued a piece of advice to stay away from such discriminatory activities and unsafe placed. However, many of these students admit that they hardly found any discriminatory and unsafe incidents for international students in China.

One of the students even explained his story about moving to China for higher studies that he was ready to go 
abroad to some European country for higher education but ... "I selected China to do my Master's degree because of no racism" (Focus Group Discussion, $2^{\text {nd }}$, September 2019).

Another student further added he was ready to leave and got a loan for higher education from a bank, but his parents were not ready to send him to EU country because of racist issues that were highlighted on the media (Focus Group Discussion, $2^{\text {nd }}$, September 2019).

Ahmad. A., Mahsood. S, (2018) study on international student's choice for higher education destinations in China observed that $62 \%$ of students selected for the survey stated that China's reputation as a safe environment has significant importance for them to select the global destination for studies. The "safety" for international students means freedom of speech, free from fierceness, and harm in the study environment of a foreign country.

One of the students from the focus group discussion said that "safety" means freedom from drugs free environment: "I actually had one of my relative who went to European country to study and he definitely did not have a good experience in terms of like the drug problems over there. Like the teenagers, and like students and colleges ... they are actually really involved in things like those (drugs)". Thus, China has exceptionally stringent laws concerning drugs free environment. The same has certainly incited my parents to allow me to go to a safe country (Focus Group Discussion, $2^{\text {nd }}$, September 2019).

The survey conducted in Chinese Universities on foreign students studying in China illustrates that $73 \%$ of students choose to study in China because of its safe environment. Ahmad. A., Mahsood. S study (2018) revealed that $62 \%$ of international students studying in China marked China as a safe place to study abroad. The current study also conforms to the study conducted by Ahmed and Mahsood regarding China as one of the safest countries for international students to study.

\subsection{Closeness to Homeland}

The OECD (2019) stated that the majority of students choose to study abroad in those countries which are close to their own country. Some students from focus group discussion also consider the discourse closeness a significant element while choosing to study abroad: "Closeness to home was one of the main factors to study in China" (Focus Group Discussion, $2^{\text {nd }}$, September 2019).

"Because it is a country near to my homeland......and it is much closer to my homeland than any other European or American universities. It is closer to my homeland and I can easily go back to my homeland during vacations". (Focus Group Discussion, $2^{\text {nd }}$, September 2019). Most of the students in this survey considered that closeness is one of the reasons they have chosen China as a destination for study, as Bangladesh, India, and Pakistan shared borders with the favorite destination such as China for their higher education.

\subsection{Cost}

The cost factor has greater significance in choosing a study destination for international students when it comes to studying abroad (LIU. Y, Peerasit K., Ando H. 2018). The reduced cost of education and living are some of the most important components which attract international students who want to pursue higher education. As some of the students from the focus group discussion highlighted, those components have greater implications and can attract international students. The student from focus group discussion said:

"UK cost of living is quite high when compared to China. So like I selected Chinese University, s which is available so..... came here in China" (Focus Group Discussion, $2^{\text {nd }}$, September 2019).

Thus China, as I already mentioned, is comparatively inexpensive as equated to England and other European countries that I have reached. Such a course is offered on the fast track; therefore, I can finish early and easily (Focus Group Discussion, $2^{\text {nd }}$, September 2019).

Many students have argued that fast track courses and the living cost, as well as the cost of education, is considered to be an attractive factor for the student who is studying in China (Robyn and Abhishek 2011). Similar to the result of the survey conducted online shows that $62 \%$ of the students are agreed that they have chosen Chinese universities because if the systematic and fast track education system/ courses. Moreover, $86 \%$ of the international students have stressed that the reason for choosing China instead of European or Western Countries is the cheaper living cost. Because the living cost is considered to be an important factor which choosing the international destination for higher education, however, the European or Western Countries may see a slight reduction in the enrollment of international students generally particularly from South Asian Countries such as Bangladesh, India, and Pakistan because of the deterioration in the value of such countries and strengthening of the value of European or Western countries. 


\subsection{Job Opportunities in China}

China considers its place as one of the emerging hubs for higher education for international students (British Council, 2012). The policy for higher education for international students in China is now allowing such graduate students to stay in China and serve the country against any competitive positions. It means the country is determined to retain its highly qualified brains to serve in the country by providing them research funding as well as highly paid jobs. The job opportunities in the mainland China as well as in Macao and Taiwan on the completion of degree is playing a pivotal role in retaining the graduates from around the globe: being an international students I don't want to go the USA, European or any Western Country as many of my friends from different cities of China are securing competitive jobs and have great employment opportunities (Focus Group Discussion, $2^{\text {nd }}$, September 2019).

I was interested in finding a job in the telecom industry as I heard China's telecom industry is considered to be a future hub; therefore, I decided not to go any other country instead of staying in China after my graduation (Focus Group Discussion, $2^{\text {nd }}$, September 2019).

The result of the online survey shows that around $56 \%$ of students have said that choosing China for higher education instead of any other US or EU universities is the more chances of getting a highly paid job in China after the completion of their degree.

\subsection{Survey: The Choice of Study Destination for International Students}

During the online survey, the students were asked to reply to a questionnaire and give your reply on a five-point Likert scale from "not at all important" to "extremely important", its significance is considered to be the diverse deliberations in selecting any educational institute for higher education. These significant levels incudes: Employment opportunities (61\%), quality of life at the campus/ facilities at the campus (49\%), Safety and security of the students (46\%), Educational cost (36\%), and available support and assistance by the government in case of starting a new business ( $26 \%$ ). The cost of living and education, facilities at the campus, and safety and security for the international students were included in the main objectives were included for the Focus Group Discussion conducted within international students studying in China.

However, most importantly, about (51\%) students from the survey expressed that quality of life at the campus has a great significance while none of the students from the focus group discussion highlighted this point. The reason for this could be the age of the students who were surveyed online; most of them were under 30 years of age, and they wanted to experience campus life in China as they could have done in any other foreign country. Interestingly, another $27 \%$ of the surveyed students highlighted the offered they were given by the government to initiate their business consequent to the completion of their degrees. Though it was not the main question of our research.

\subsection{Survey: International Education Agents/ Education Consultants}

The students from both the Survey and Focus Group Discussion had asked the same question about what kind of information International Education Agents offered to these students. About $76 \%$ of the students from the Focus Group Discussion replied that they contacted the education agents from their own countries. They got information from such agents about admission, degree programme, and its duration, visa requirement, accommodation at the campus, and process of their application for admission. While $31 \%$ of students from the survey replied that Education Agents have somewhat guided them in choosing the destination for higher education. The information given by these Educational Agents was more of a university for the students instead of which country is more suitable for a certain programme for international students. Some of the agents are required by the Chinese Universities to provide information about the programme and only invite them to the course and assist them in the visa application and enrollment at the campus. The International Education Agents said that most of the students were already known to the courses and progrmame in which they want to pursue their studies because the information regarding programmes and courses offered by the concerned universities were available online.

\section{Conclusion}

The study aimed to comprehend the motive of foreign students in selecting Chinese universities for tertiary education. To be able to complete this study the concept of discourse analysis had used from focus group discussion, resultantly, the study identified these international students have different discourses ranging from global exposure, safety and security, racism, cultural experience, financial hubs, job opportunities and most importantly cost of education and accommodation at the destination of studies.

International Students expressed in an online survey that mainly students choose the study destination 
irrespective to their own countries due to highly qualitative education taught in foreign universities, to strengthen their academic capacity, and to enhance foreign education exposure, research, and professional profile to have competitive employment opportunities. The result of the study could have been different if the study had not been limited to one university. Yet, it is unlikely to say that difference in the representation of Chinese Universities could influence the results of the overall study as the main focus of the study was on investigate why international students choose Chinese Universities, not any particular Chinese University. The majority of such students choose to study in Chinese Universities because of safety and security at the campus, geographical closeness to their respective countries, cheaper education, and accommodation cost as compared to any other US or European countries. Additionally, the Chinese Universities were chosen because of their systematic and fast track course schedule and an overall reduction in the cost of study. The result of the study concludes that China is considered to be the emerging and favorite country for tertiary education for foreign students.

Many students from the Focus Group Discussion and Student Survey expressed their views for not choosing any US or European universities because they don't consider them as a safe study destination as they consider Chinese Universities. Further research on the causes of not choosing any US or European universities could be conducted with the help of respective countries to find the solution which could be beneficial for these countries.

\section{Suggestions}

The enrollment of international students in tertiary education worldwide is becoming more globalized because of the globalization of economies, societies. International education and students are playing a pivotal role in the Chinese economy, society and therefore, further research on this topic could have done to increase the number of international student's enrollment in China, particularly among South Asian countries. As a result of the study revealed about $49 \%$ of surveyed students stated that the quality of life at the campus has a greater significance. Therefore, further research on the different aspects of the life of international students on the campus could be valuable for China. Research on the exposure of international students, as well as enrollment, can be gradually developed by introducing policy changes in education for international students. It is further suggested that research can be conducted on the reasons why international students from the selected countries are decreasing, especially in tertiary education, which may help the government and universities to introduce friendly policies for international students.

\section{References}

Ahmad, A. B., \& Shah, M. (2018). International students' choice to study in China: an exploratory study. Tertiary Education and Management, 24(4), 325-337. https://doi.org/10.1080/13583883.2018.1458247

British Council. (2012). The shape of things to come: higher education global trends and emerging opportunities to 2020. Retrieved September 7, 2019, from https://www.britishcouncil.org/sites/default/files/the_shape_of_things_to_come_-_higher_education_global _trends_and_emerging_opportunities_to_2020.pdf

Chen, K. (2016). International Student Mobility in Higher Education in China: Tensions between Policies and Practices.

Ferencz, I. (2015). Balanced Mobility Across the Board-A Sensible Objective?. In The European Higher Education Area (pp. 27-41). Springer, Cham. https://doi.org/10.1007/978-3-319-20877-0_3

Huang, F. (2015). Building the world-class research universities: A case study of China. Higher Education, 70(3), 203-215. https://doi.org/10.1007/s10734-015-9876-8

Institute of International Education. (2015a). Open Doors Report 2015. Retrieved October 25, 2019, from http://www.iie.org/ Research-and-Publications/Open-Doors

Institute of International Education. (2017). International students. Retrieved October 17, 2019, from https://www.iie.org/Research-and-Insights/Open-Doors/Data/International-Students

Jiani, M. A. (2017). Why and how international students choose Mainland China as a higher education study abroad destination. Higher Education, 74(4), 563-579. https://doi.org/10.1007/s10734-016-0066-0

Jon, J. E., Lee, J. J., \& Byun, K. (2014). The emergence of a regional hub: Comparing international student choices and experiences in South Korea. Higher Education, 67(5), 691-710. https://doi.org/10.1007/s10734-013-9674-0

Knowles, J. G., \& Cole, A. L. (2008). Handbook of the arts in qualitative research: Perspectives, methodologies, examples, and issues. Sage. https://doi.org/10.4135/9781452226545 
Li, T. (2000). Chinese studying abroad education history (after 1949). Beijing: Higher Education Press.

Liu, Y., Kamnuansilpa, P., \& Hirofumi, A. (2018). Factors Affecting International Students' Decisions on Destination for Studying Abroad: A Case Study in China. Frontiers of Education in China, 13(1), 93-118. https://doi.org/10.1007/s11516-018-0004-2

Marginson, S. (2011). Higher education in East Asia and Singapore: Rise of the Confucian model. Higher Education, 61(5), 587-611. https://doi.org/10.1007/s10734-010-9384-9

Maringe, F., \& Foskett, N. (Eds.). (2012). Globalization and internationalization in higher education: Theoretical, strategic and management perspectives. A\&C Black.

Ministry of Education. (2012). Plan for Study in China. Retrieved October 24, 2019, from http://en.moe.gov.cn/documents/reports/201901/t20190115_367019.html

Ministry of Education. (2018). Statistical report on international students in China for 2018. Retrieved October 21, 2019, from http://en.moe.gov.cn/documents/reports/201904/t20190418_378692.html

Ministry of Foreign Affairs PRC. (2014). Speech by H.E. Mr. Xi Jinping President of the People's Republic of China at the Meeting Commemorating the 50th Anniversary of the Establishment of China-France Diplomatic Relations. Retrieved November 18, 2019, from https://www.fmprc.gov.cn/mfa_eng/topics_665678/xjpzxcxdsjhaqhfbfwhlfgdgblshlhgjkezzzbomzb_666590 /t1147894.shtml

Schleicher, A. (2018). How to build a 21st-century school system. Paris: OECD. https://doi.org/10.1787/9789264300002-en

ShuHong, Y., Zia-ud-Din, M., Khan, R. D., \& Bilal, S. (2018). Cross-National Comparative Study on Legal Education and Admission to Practice Between China, India and Pakistan. Journal of legal studies, 21(35), 16-37. https://doi.org/10.1515/jles-2018-0002

UNESCO. (2018). INTERNATIONALIZATION OF HIGHER EDUCATION AND STUDENT MOBILITY IN JAPAN AND ASIA, Background paper prepared for the 2019 Global Education Monitoring Report Migration, displacement and education: Building bridges, not walls.

Waldrop, N. (2016). Educating the enemy: Chinese students and the Sino-American Cold War, 1948-1955.

Wei, H. (2013). An empirical study on the determinants of international student mobility: A global perspective. Higher Education, 66(1), 105-122. https://doi.org/10.1007/s10734-012-9593-5

Wen, W., Hu, D., \& Hao, J. (2018). International students' experiences in China: Does the planned reverse mobility work?. International Journal of Educational Development, 61, 204-212. https://doi.org/10.1016/j.ijedudev.2017.03.004

\section{Copyrights}

Copyright for this article is retained by the author(s), with first publication rights granted to the journal.

This is an open-access article distributed under the terms and conditions of the Creative Commons Attribution license (http://creativecommons.org/licenses/by/4.0/). 